Respiration 2018;95:72-72

DOI: $10.1159 / 000481203$

\section{On the Relation of Pseudomonas aeruginosa Infection and Respiratory Muscle Function in Adolescents and Adults with Cystic Fibrosis}

\author{
Theodore Dassios ${ }^{\mathrm{a}, \mathrm{b}}$ Gabriel Dimitriou ${ }^{\mathrm{b}}$ \\ a Department of Child Health, King's College Hospital NHS \\ Foundation Trust, London, UK; ${ }^{\mathrm{b}}$ Department of Paediatrics, \\ University of Patras, Patras, Greece
}

We read with interest the study by Magnet et al. [1] which evaluated the impact of Pseudomonas aeruginosa $(\mathrm{Pa})$ infection on respiratory muscle function in adult cystic fibrosis $(\mathrm{CF})$ patients. The authors studied 51 adults with CF and used the pressure-time index of the respiratory muscles $\left(\mathrm{PTI}_{\text {mus }}\right)$ to evaluate respiratory muscle efficiency. They concluded that $\mathrm{PTI}_{\text {mus }}$ was not different in adult $\mathrm{CF}$ patients infected with $\mathrm{Pa}$ compared to the ones that were not infected with $\mathrm{Pa}$. The study used similar methodology and contrasted the results of a previous study of ours in adolescents with $\mathrm{CF}$, where we found that chronic $\mathrm{Pa}$ infection was an independent determinant of $\mathrm{PTI}_{\text {mus }}$ [2]. Magnet et al. [1], thus, suggested that the findings in adolescent CF patients cannot be extrapolated to the adult CF population.

Methodologically, we welcome the incorporation of measurements of residual volume and the 6-minute walk test (6MWT), which would allow elucidating the effect that hyperinflation and distance walked, respectively, have on respiratory muscle function. The logistics of this study are indeed demanding, since respiratory muscle function in CF is influenced by numerous interrelated parameters, such as airway obstruction [3], hyperinflation [4], nutrition $[5,6]$, aerobic exercise [7], use of steroids [8] and, according to our results, the presence of chronic infection with $\mathrm{Pa}$ [2]. Controlling for these parameters as possible confounders would require a considerable sample size which is often bigger than the average $\mathrm{CF}$ centre. Moreover, as the authors comment, excluding significant numbers of adult patients on the basis of existing co-infections could render the study unfeasible. In an effort to address these concerns in our study, we only studied patients with mild to moderate airway obstruction and excluded patients on steroids and patients with co-existing pathogens other than Staphylococcus aureus and Haemophilus influenzae; hence, we included 122 patients [2].

Although previous studies have described that airway obstruction [3] and reported aerobic exercise [7] are determinants of respiratory muscle function in CF patients, in the multivariate regression analysis of Magnet et al. [1], $\mathrm{FEV}_{1}$ and the 6MWT were not independent contributors to alterations of $\mathrm{PTI}_{\text {mus. }}$. One might, thus, wonder whether a sample size calculation that would have taken into account the known confounders and their interactions might have had an impact on the reported lack of association of $\mathrm{PTI}_{\text {mus }}$ with the known determinants of respiratory muscle function in CF.
The authors present a highly significant correlation of $\mathrm{PTI}_{\text {mus }}$ with occlusion pressure and maximal inspiratory pressure, which is hardly surprising given that these are the main components of the equation used to calculate $\mathrm{PTI}_{\text {mus }}$ [9]. The use of the body mass index should also be viewed with some caution, as previous studies have described that respiratory muscle function does not correlate with the body mass index [10] but is significantly related to indices of somatic muscularity, such as lean body mass [4]. Thus, body composition parameters, such as fat-free mass, would probably be better equipped to describe the relation of malnutrition with respiratory muscle function in CF $[5,6]$.

Finally, while the authors present the number of different pathogens in the study population, it would be interesting to see whether $\mathrm{PTI}_{\text {mus }}$ is different when the infected patients (both $\mathrm{Pa}$ and co-pathogens grouped together) are compared to the noninfected ones.

Financial Disclosure and Conflicts of Interest

There are no conflicts of interest to declare.

\section{Funding Sources}

There were no funding sources.

\section{References}

1 Magnet FS, Callegari J, Dieninghoff D, Spielmanns M, Storre JH, Schmoor C, Windisch W: Impact of Pseudomonas aeruginosa infection on respiratory muscle function in adult cystic fibrosis patients. Respiration 2017;93:42-50.

2 Dassios TG, Katelari A, Doudounakis S, Dimitriou G: Chronic Pseudomonas aeruginosa infection and respiratory muscle impairment in cystic fibrosis. Respir Care 2014;59:363-370.

3 Hahn A, Ankermann T, Claass A, Mann M, Lindemann H, Neubauer BA: Non-invasive tension time index in relation to severity of disease in children with cystic fibrosis. Pediatr Pulmonol 2008;43:973-981.

4 Hayot M, Guillaumont S, Ramonatxo M, Voisin M, Prefaut C: Determinants of the tension-time index of inspiratory muscles in children with cystic fibrosis. Pediatr Pulmonol 1997;23:336-343.

5 Enright S, Chatham K, Ionescu AA, Unnithan VB, Shale DJ: The influence of body composition on respiratory muscle, lung function and diaphragm thickness in adults with cystic fibrosis. J Cyst Fibros 2007;6:384-390.

6 Ionescu AA, Chatham K, Davies CA, Nixon LS, Enright S, Shale DJ: Inspiratory muscle function and body composition in cystic fibrosis. Am J Respir Crit Care Med 1998;158:1271-1276.

7 Dassios T, Katelari A, Doudounakis S, Dimitriou G: Aerobic exercise and respiratory muscle strength in patients with cystic fibrosis. Respir Med 2013;107:684-690.

8 Pinet C, Scillia P, Cassart M, Lamotte M, Knoop C, Melot C, et al: Preferential reduction of quadriceps over respiratory muscle strength and bulk after lung transplantation for cystic fibrosis. Thorax 2004;59:783789 .

9 Gaultier C: Tension-time index of inspiratory muscles in children. Pediatr Pulmonol 1997;23:327-329.

10 Dassios T, Katelari A, Doudounakis S, Mantagos S, Dimitriou G: Respiratory muscle function in patients with cystic fibrosis. Pediatr Pulmonol 2013;48:865-873.

\section{KARGER}

(C) 2017 S. Karger AG, Basel

E-Mail karger@karger.com

www.karger.com/res
Theodore Dassios

NICU, 4th Floor Golden Jubilee Wing

King's College Hospital, Denmark Hill

London SE5 9RS (UK)

E-Mail theodore.dassios@ kcl.ac.uk 